Baseline

\title{
Assessment of heavy metal impact on sediment quality of the Xiaoqinghe estuary in the coastal Laizhou Bay, Bohai Sea: Inconsistency between two commonly used criteria
}

\author{
Wen Zhuang ${ }^{\mathrm{a}, \mathrm{b}, \mathrm{c}}$, Xuelu Gao ${ }^{\mathrm{a}, *}$ \\ ${ }^{a}$ Key Laboratory of Coastal Environmental Processes and Ecological Remediation, Yantai Institute of Coastal Zone Research, Chinese Academy of Sciences, \\ Yantai, Shandong 264003, China \\ ${ }^{\mathrm{b}}$ College of City and Architecture Engineering, Zaozhuang University, Zaozhuang, Shandong 277160, China \\ ${ }^{\mathrm{c}}$ University of Chinese Academy of Sciences, Beijing 100049, China
}

\section{A R T I C L E I N F O}

\section{Article history}

Available online 13 April 2014

\section{Keywords:}

Marine pollution

Environmental surveys

Sediment analysis

Coastal zone

Geochemistry

China

\begin{abstract}
A B S T R A C T
Surface sediments in the Xiaoqinghe estuary, southwestern coastal Laizhou Bay, were examined to assess the bio-toxic risk of heavy metals $(\mathrm{Cd}, \mathrm{Cu}, \mathrm{Ni}, \mathrm{Pb}$ and $\mathrm{Zn})$ with the effects range-low and effects rangemedian guidelines (ERL-ERMs) and the concentration ratio of simultaneously extractable metals to acid volatile sulfides ([SEM]/[AVS]). Based on the ERL-ERM guidelines, bio-toxic effect caused by $\mathrm{Cu}, \mathrm{Ni}, \mathrm{Pb}$ and $\mathrm{Zn}$ could be expected in the riverine surface sediments of the Xiaoqinghe estuary; and the surface sediments in the marine area were in good quality and only Ni might cause bio-toxic effect occasionally. The AVS-SEM guidelines revealed that no bio-toxic effect could be caused by any of the studied metals in both the riverine and marine sediments, since there were excess sulfides in surface sediments which could form water-insoluble substances with free metal ions and reduce the bioavailability of heavy metals.
\end{abstract}

(c) 2014 Elsevier Ltd. All rights reserved.
Heavy metals in aquatic ecosystems have received extensive attention because they are toxic, non-biodegradable in the environment and can accumulate in organisms. Due to the discharge of industrial effluents, agriculture wastewater and sewage runoff, concentrations of heavy metals in aquatic ecosystems have increased considerably (Prica et al., 2008; Yang et al., 2012; Gao et al., 2014). Sediment is not only an important reservoir of heavy metals in aquatic ecosystems, but also is an important source of heavy metals for the overlying water (van Den Berg et al., 1999; Wilson and Chang, 2000; Prica et al., 2008).

Effects range-low and effects range-median (ERL-ERM) guidelines are sediment quality guidelines (SQGs) which can indicate the levels of metal concentrations at which toxicity may be observed and above which adverse effects are expected. They are empirical approaches based on total concentrations of metals (Long et al., 1995; Hinkey and Zaidi, 2007). Acid volatile sulfidessimultaneously extractable metals (AVS-SEM) guideline is based on the relationship between the molar concentrations of AVS

\footnotetext{
* Corresponding author. Address: Key Laboratory of Coastal Environmental Processes and Ecological Remediation, Yantai Institute of Coastal Zone Research, Chinese Academy of Sciences, 17 Chunhui Road, Yantai, Shandong 264003, China. Tel.: +86535 2109132; fax: +865352109000.

E-mail address: xlgao@yic.ac.cn (X. Gao).
}

([AVS], $\mu \mathrm{mol} \mathrm{g}^{-1}$ ) and SEM ([SEM], $\mu \mathrm{mol} \mathrm{g}^{-1}$ ) and has been proposed as a possible indicator of metal toxicity in sediments (Long et al., 1998; Liu et al., 2010). When the ratio [SEM]/[AVS] is > 1 or $[\mathrm{SEM}]-[\mathrm{AVS}]>0$, toxicity may be generated by heavy metals, whereas the generation of toxicity is less possible when [SEM]/ [AVS] < 1 or [SEM]-[AVS] < 0 (Di Toro et al., 1990; Ankley et al., 1996; USEPA, 2004; Di Toro et al., 2005). ERL-ERM and AVS-SEM guidelines are criteria commonly used in the assessment of biotoxic risks posed by heavy metals in sediments.

Both the ERL-ERM and AVS-SEM criteria have been validated by sufficient research into numerous sites and the corresponding data in the United States (Long et al., 1998; McGrath et al., 2002; Wenning and Ingersoll, 2002). These methods are now used around the world for informal (non-regulatory) and screening purposes for enforcement, although caution has been advised in using these methods due to limitations and uncertainties associated with different approaches (Wenning and Ingersoll, 2002). Taking many factors into consideration such as redox potential, dissolved oxygen, topography, moisture content and anthropogenic influence, bio-toxic levels of heavy metals in different sediments could be different even with similar dry weight concentrations (McGrath et al., 2002; Wenning and Ingersoll, 2002; Zhuang and Gao, 2013). 
The Xiaoqinghe River is located in Shandong Province, China. The length of the Xiaoqinghe River is $240 \mathrm{~km}$ with the basin area of $11,000 \mathrm{~km}^{2}$. It originates in Jinan City - the capital city of Shandong Province, and flows into the Laizhou Bay in the southern Bohai Sea in Shouguang City - the most important producer of vegetables in China. Among the rivers discharging into the southwestern coast of the Laizhou Bay, the Xiaoqinghe River is a relatively big one with extensive reconstruction for flood control, sailing, irrigation, and sewage discharge. The mean river width of the studied area is $100-120 \mathrm{~m}$ with a width of over $300 \mathrm{~m}$ in the river mouth (Chen et al., 2009). The mean river depth of the studied area is $2-3 \mathrm{~m}$, and the depth of the sea area near its estuary is within $10 \mathrm{~m}$ (Cui et al., 2013). A huge amount of pollutants are directly discharged into the Xiaoqinghe River which has led to the deterioration of its aquatic environment. Riverine sediment load of the Xiaoqinghe River has been decreasing from the second half of the 20th century, whereas the amount of the contaminants brought by it has been increasing with years (Ma et al., 2004). In 2008, 33 tons of heavy metals were discharged into the Laizhou Bay by the Xiaoqinghe River (SOA, 2009), and the number soared to 384 tons in 2011 (SOA, 2012). The worsening pollution of heavy metals not only threatens the health of coastal residents, but also might bring serious damage to the fishery resources of the Laizhou Bay. Therefore it is important to monitor and understand the pollution status and bioavailability of heavy metals in this area.

So far, there is no report on the bio-toxic risk assessment of heavy metals in sediments of the Xiaoqinghe River. This study examined the concentrations of AVS, SEM and the total concentrations of heavy metals in the surface sediments of the lowermost Xiaoqinghe River and the southwestern offshore area of the Laizhou Bay near its river mouth. The purposes of this study are to (a) quantify and explain the spatial distribution of five heavy metals, namely $\mathrm{Cd}$, $\mathrm{Cu}, \mathrm{Ni}, \mathrm{Pb}$ and $\mathrm{Zn}$, the geochemical activities of which are greatly impacted by sulfides, in the surface sediments of the Xiaoqinghe estuary in the coastal Laizhou Bay, (b) assess the bio-toxic risks posed by heavy metals based on ERL-ERM and AVS-SEM guidelines, and (c) investigate the differences between the two guidelines in the bio-toxic risk assessment of heavy metals.

An investigation focusing on the surface sediment quality was carried out in the southwestern coastal Laizhou Bay in September-October 2012 covering its sublittoral zone and the lowermost areas of the major rivers it connects with (Zhuang and Gao, 2013). The sampling sites were arranged along the Xiaoqinghe River extending from the land to the offshore area of the Laizhou Bay, covering an area of about $25 \mathrm{~km}$ from the high tide mark to the land and about $10 \mathrm{~km}$ from the high tide mark to the sea (Fig. 1). Site XQH1 was located near the river mouth, site XQH2 was near a dilapidated wharf, site $\mathrm{XQH} 3$ was at a ferry pier, and site $\mathrm{XQH} 4$ was located near a bridge. Sites K1-K3 were located in the offshore area of the Laizhou Bay in the direction of the river flowing. The surface sediments of the top $5 \mathrm{~cm}$ from the riverine sites were collected using a plastic spatula from the shallow water near the riverside, and the surface sediments from the marine sites were collected with a stainless steel grab sampler. The samples were placed in acid cleaned polyethylene bottles without any space left or with a nitrogen atmosphere immediately after sampling, and stored in a cooler box with ice bags, and then frozen at $-20^{\circ} \mathrm{C}$ within $12 \mathrm{~h}$ until further analysis.

Redox potential (Eh) and $\mathrm{pH}$ of sediments were determined on the sampling sites immediately after the sample collection with redox and $\mathrm{pH}$ electrodes, respectively. To convert the contents of geochemical parameters in the sediments from a wet weight basis to a dry weight basis, the moisture content (MC) was determined by measuring the weight losses of the samples after the drying at $105^{\circ} \mathrm{C}$ until constant weights were obtained. Total organic carbon (TOC) concentrations in sediments were obtained by determining

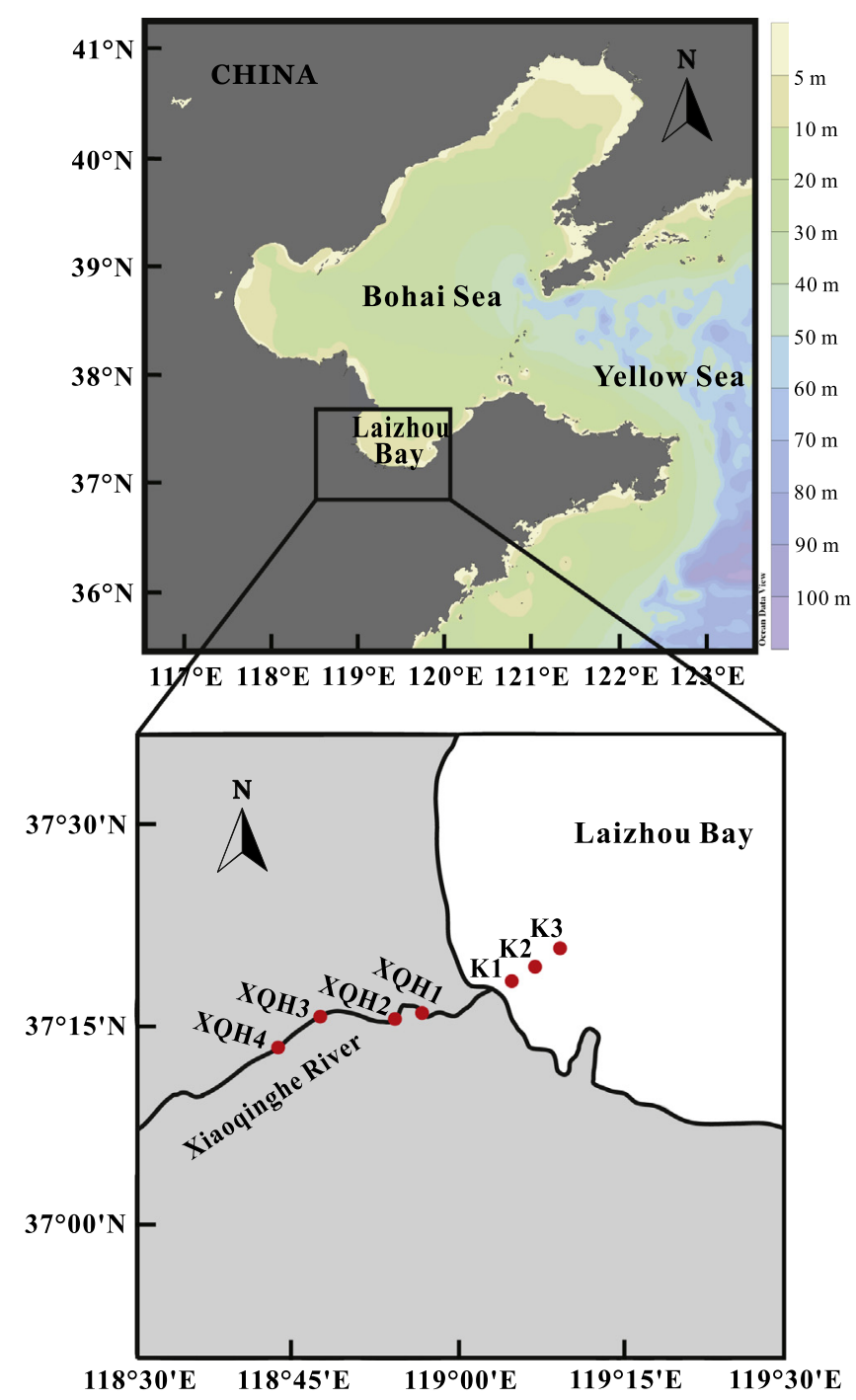

Fig. 1. Location of sampling sites in the Xiaoqinghe estuary.

the total carbon with an Elementar vario MACRO cube CHNS analyzer after removing the inorganic carbon with $1 \mathrm{M} \mathrm{HCl}$. The grain size distribution was analyzed with a particle size analyzer (Mastersizer 2000, Malvern, Britain) capable of analyzing particle sizes between 0.02 and $2000 \mu \mathrm{m}$. The percentages of the following three groups of grain sizes were determined: $<4 \mu \mathrm{m}$ (clay), 4-63 $\mu \mathrm{m}$ (silt), and $>63 \mu \mathrm{m}$ (sand) (Gao and Chen, 2012).

A diffusion method described by van Griethuysen et al. (2002) was used to extract AVS in this study. For each extraction, $5 \mathrm{ml}$ $6 \mathrm{M} \mathrm{HCl}$ was added to $3 \mathrm{~g}$ wet sediment. The volatile hydrogen sulfide $\left(\mathrm{H}_{2} \mathrm{~S}\right)$ was collected in $10 \mathrm{ml}$ sulfide antioxidant buffer (SAOB). The SAOB solution contained $2 \mathrm{M} \mathrm{NaOH}, 0.2 \mathrm{M}$ ascorbic acid and $0.2 \mathrm{M}$ disodium EDTA, which was the same as that used by van Griethuysen et al. (2002). The amount of free sulfur ions in SAOB buffer was measured with an ion specific electrode (van Griethuysen et al., 2002; De Jonge et al., 2012). Quality of AVS extraction was ensured by calibrating the procedure against known amounts of $\mathrm{Na}_{2} \mathrm{~S} \cdot 9 \mathrm{H}_{2} \mathrm{O}$ (Durán et al., 2012), and recoveries were within $85-94 \%$. Replicates for all the samples were made as a part of the quality assurance and the relative standard deviations were within $10 \%$. Concentrations of the SEM components (i.e. Cd, $\mathrm{Cu}, \mathrm{Ni}, \mathrm{Pb}$, and $\mathrm{Zn}$ ) in sediments were measured by an inductively coupled plasma-optical emission spectrometer (ICP-OES; Optima model 7000DV, PerkinElmer, USA). 
The mixture of $8 \mathrm{ml}$ concentrated $\mathrm{HF}, \mathrm{HNO}_{3}$ and $\mathrm{HClO}_{4}(5: 2: 1)$ was used for the total digestion of heavy metals in $0.1 \mathrm{~g}$ sediment (dry weight) (Li et al., 2000). The volume of the samples was then increased to $40.0 \mathrm{ml}$ with $2 \% \mathrm{HNO}_{3}(\mathrm{w} / \mathrm{w}$ ) in a polyethylene bottle and stored at $4{ }^{\circ} \mathrm{C}$ until instrumental analysis. Replicates for all the samples were also made, and the relative standard deviations were less than $10 \%$. Inductively coupled plasma mass spectrometry (ICPMS; Elan DRC II, PerkinElmer, USA) was applied in this work to determine the concentrations of $\mathrm{Cd}, \mathrm{Cu}, \mathrm{Ni}, \mathrm{Pb}$ and $\mathrm{Zn}$ in the aforementioned digested sediment samples. The Chinese national geo-standard samples of GBW07314 and GBW07333 were used to control the analytical quality. The results were consistent with the reference values, and the differences were all less than $10 \%$.

All results were expressed on the basis of the dry weight of the sediment. All reagents were analytical or guaranteed grade. All the labwares (bottles, tubes, etc.) were pre-cleaned by soaking in $10 \%$ $\mathrm{HNO}_{3}(\mathrm{v} / \mathrm{v})$ for at least 2 days, followed by soaking and rinsing with de-ionized water.

ERL-ERM guidelines have been used to judge the potential adverse effects of $\mathrm{Cd}, \mathrm{Cu}, \mathrm{Pb}, \mathrm{Ni}$ and $\mathrm{Zn}$ on the sedimentary biota. The AVS-SEM method, which was used as one of the sediment quality assessment criteria by the United States Environmental Protection Agency (USEPA, 2004), was also applied to assess the potential bio-toxicity of heavy metals.

The concentrations of heavy metals and the values of ERM-ERL guidelines were shown in Table 1 . The highest total metal concentration (the sum of five metals) was found at site $\mathrm{XQH3}$ $\left(613.0 \mu \mathrm{g} \mathrm{g}^{-1}\right)$ which was at a ferry pier, and the lowest value was at site $\mathrm{K} 3\left(87.5 \mu \mathrm{g} \mathrm{g}^{-1}\right)$ which was in the marine area. The total metal concentrations at the sampling sites (except XQH4) showed a decreasing trend in the direction of the river run-off. The mean concentrations of heavy metals were in the order: $\mathrm{Cd}<\mathrm{Pb}<\mathrm{Ni}<\mathrm{Cu}<\mathrm{Zn}$.

The concentrations of $\mathrm{Ni}$ in the sediments from all the sampling sites except K3 exceeded its ERL value. The concentrations of Cd were lower than its ERL value at all sites. The concentrations of $\mathrm{Cu}$ and $\mathrm{Ni}$ exceeded their corresponding ERL values and the concentration of $\mathrm{Zn}$ exceeded its ERM value at site QXH4. The concentrations of $\mathrm{Cu}, \mathrm{Ni}$ and $\mathrm{Pb}$ were higher than their corresponding ERL values and the concentration of $\mathrm{Zn}$ was higher than its ERM values at site QXH3. At sites XQH2, XQH1, K1 and K2, only the concentration of Ni exceeded its ERL values. The concentrations of all the studied metals were lower than their corresponding ERL values at site $\mathrm{K} 3$.

Sediment characteristics, concentrations of AVS and SEM, and assessments of bio-toxicity of heavy metals were shown in Table 2. Generally, the concentrations of AVS and SEM in the surface sediments of the Xiaoqinghe River were higher than those of the marine area. The average concentrations of SEM components were in the following order: $[\mathrm{SEM}]_{\mathrm{Cd}} \ll[\mathrm{SEM}]_{\mathrm{Pb}}<[\mathrm{SEM}]_{\mathrm{Ni}}<[\mathrm{SEM}]_{\mathrm{Cu}}<$ $[S E M]_{Z n}$ (Fig. 2). Although metal concentrations were at a high level, the ratios of [SEM]/[AVS] at all sites were $<1$ and the [SEM]-[AVS] values were all negative, indicating low bio-toxicity.

Total heavy metal concentrations in the riverine surface sediments were much higher than those in the sediments from the marine area (Table 1). The highest total concentration of the five studied metals was observed at site XQH3 which was located at a ferry pier. The high content of heavy metals in its sediment was likely to be derived from anthropogenic activities. Ferry activities-related metals such as $\mathrm{Cu}$ and $\mathrm{Zn}$ are usually released from the anti-corrosion paints used on ship hulls during the maintenance of ships (Guillen et al., 1993; Hinkey et al., 2005; Hinkey and Zaidi, 2007). The excessive input of Cd into aquatic environments induced by the utilization of phosphorus fertilizer has been widely reported (Lambert et al., 2007; Zhang and Shan, 2008). The second highest total concentration of the five studied metals was observed at site XQH4 which was located near a bridge. Site XQH4 was also influenced by intense human activities. Exhausted gas emitted by vehicles could lead to the increase in contents of heavy metals in the environments surrounding the roads with heavy traffic; the studied metals might also be from point sources such as domestic sewage and factory wastewater discharge (Gao et al., 2014). Due to the weakening of the intensity of human activities that discharge heavy metals, total heavy metal concentrations in sediments gradually decreased from the riverine region to the marine region with the decrease of the amount of heavy metal input.

At sites $\mathrm{XQH} 3$ and $\mathrm{XQH} 4$ which were more frequently influenced by human activities, higher AVS concentrations were observed (Table 2); this might be attributed to the sulfide-rich waste discharged from domestic sewage and industrial effluents and the sharp metabolism of sulfate reducing bacteria in riverine sediments (Zhuang and Gao, 2013). The mean concentrations of SEM and all of its components in the riverine sediments were apparently higher than their corresponding values in the marine sediments, and this distribution feature was in accordance with that of their total concentrations in the sediments, indicating the impact of human activities and surface run-off on the spatial distribution of heavy metals. $\mathrm{Zn}$ was the most dominant component of SEM in all samples and accounted for approximately 43.5-78.0\% of the concentrations of SEM, whereas the contribution of $\mathrm{Cd}$ - the most toxic one among those metals that were studied in this research - to SEM was no more than $1 \%$. Soares et al. (1999) reported that heavy metals from anthropogenic inputs were more loosely bound to sediments and were more easily released back into the aqueous phase with the change of physical and chemical characteristics of aquatic environments such as $\mathrm{Eh}, \mathrm{pH}$, salinity

Table 1

Heavy metal concentrations in the surface sediments of the Xiaoqinghe estuary.

\begin{tabular}{|c|c|c|c|c|c|c|c|c|c|c|c|c|}
\hline \multirow[t]{2}{*}{ Site } & \multicolumn{2}{|l|}{$\mathrm{Cd}$} & \multicolumn{2}{|l|}{$\mathrm{Cu}$} & \multicolumn{2}{|l|}{$\mathrm{Ni}$} & \multicolumn{2}{|l|}{$\mathrm{Pb}$} & \multicolumn{2}{|l|}{$\mathrm{Zn}$} & \multicolumn{2}{|l|}{ Total } \\
\hline & $\mu \mathrm{g} \mathrm{g}^{-1}$ & $\mu \mathrm{mol} \mathrm{g}^{-1}$ & $\mu \mathrm{g} \mathrm{g}^{-1}$ & $\mu \mathrm{mol} \mathrm{g}^{-1}$ & $\mu \mathrm{g} \mathrm{g}^{-1}$ & $\mu \mathrm{mol} \mathrm{g}^{-1}$ & $\mu \mathrm{g} \mathrm{g}^{-1}$ & $\mu \mathrm{mol} \mathrm{g}^{-1}$ & $\mu \mathrm{g} \mathrm{g}^{-1}$ & $\mu \mathrm{mol} \mathrm{g}^{-1}$ & $\mu \mathrm{g} \mathrm{g}^{-1}$ & $\mu \mathrm{mol} \mathrm{g}^{-1}$ \\
\hline $\mathrm{XQH} 4$ & 0.63 & 0.0056 & $61.16^{\mathrm{a}}$ & $0.96^{\mathrm{a}}$ & $35.48^{a}$ & $0.60^{\mathrm{a}}$ & 32.34 & 0.16 & $442.02^{b}$ & $6.75^{b}$ & 571.63 & 8.48 \\
\hline $\mathrm{XQH3}$ & 0.74 & 0.0066 & $72.85^{\mathrm{a}}$ & $1.15^{\mathrm{a}}$ & $44.19^{\mathrm{a}}$ & $0.75^{\mathrm{a}}$ & $49.18^{\mathrm{a}}$ & $0.24^{\mathrm{a}}$ & $446.04^{\mathrm{b}}$ & $6.81^{\mathrm{b}}$ & 613.00 & 8.96 \\
\hline $\mathrm{XQH} 2$ & 0.39 & 0.0035 & 31.30 & 0.49 & $29.44^{\mathrm{a}}$ & $0.50^{\mathrm{a}}$ & 19.12 & 0.09 & 143.38 & 2.19 & 223.63 & 3.27 \\
\hline $\mathrm{XQH} 1$ & 0.39 & 0.0035 & 25.46 & 0.40 & $28.38^{\mathrm{a}}$ & $0.48^{\mathrm{a}}$ & 17.09 & 0.08 & 99.46 & 1.52 & 170.78 & 2.48 \\
\hline $\mathrm{K} 1$ & 0.27 & 0.0024 & 14.88 & 0.23 & $21.38^{a}$ & $0.36^{\mathrm{a}}$ & 16.88 & 0.08 & 106.36 & 1.62 & 159.77 & 2.29 \\
\hline K2 & 0.27 & 0.0024 & 11.02 & 0.17 & $22.26^{\mathrm{a}}$ & $0.38^{\mathrm{a}}$ & 17.52 & 0.08 & 56.89 & 0.87 & 107.96 & 1.50 \\
\hline K3 & 0.45 & 0.0040 & 11.72 & 0.18 & 19.00 & 0.32 & 15.06 & 0.07 & 41.24 & 0.63 & 87.47 & 1.20 \\
\hline Mean & 0.45 & 0.0040 & 32.63 & 0.51 & $28.59^{\mathrm{a}}$ & $0.49^{\mathrm{a}}$ & 23.89 & 0.12 & $190.77^{\mathrm{a}}$ & $2.91^{\mathrm{a}}$ & & \\
\hline ERL guideline & 1.2 & 0.0107 & 34 & 0.54 & 20.9 & 0.36 & 47 & 0.23 & 150 & 2.29 & & \\
\hline ERM guideline & 9.6 & 0.0854 & 270 & 4.25 & 51.6 & 0.88 & 218 & 1.05 & 410 & 6.26 & & \\
\hline
\end{tabular}

\footnotetext{
a Metal concentrations exceeded ERLs.
}

b Metal concentrations exceeded ERMs. 
Table 2

AVS and SEM concentrations, the ratios and differences between them, and the values of geochemical parameters in the surface sediments of the Xiaoqinghe estuary.

\begin{tabular}{|c|c|c|c|c|c|c|c|c|c|c|c|}
\hline Site & {$[\mathrm{AVS}]\left(\mu \mathrm{mol} \mathrm{g}^{-1}\right)$} & {$[\mathrm{SEM}]\left(\mu \mathrm{mol} \mathrm{g}^{-1}\right)$} & [SEM]/[AVS] & {$[\mathrm{SEM}]-[\mathrm{AVS}]\left(\mu \mathrm{mol} \mathrm{g}^{-1}\right)$} & Clay (\%) & Silt (\%) & Sand (\%) & TOC (\%) & MC (\%) & $\mathrm{pH}$ & Eh $(\mathrm{mV})$ \\
\hline $\mathrm{XQH} 4$ & 16.36 & 3.92 & 0.24 & -12.44 & 13.5 & 73.2 & 13.4 & 0.89 & 57.4 & 7.53 & -155 \\
\hline $\mathrm{XQH3}$ & 15.50 & 4.62 & 0.30 & -10.88 & 15.6 & 75.2 & 9.2 & 0.59 & 59.1 & 7.50 & -209 \\
\hline $\mathrm{XQH} 2$ & 11.46 & 1.35 & 0.12 & -10.11 & 15.2 & 56.9 & 27.9 & 3.82 & 38.1 & 7.19 & -112 \\
\hline $\mathrm{XQH} 1$ & 8.49 & 1.07 & 0.13 & -7.42 & 15.9 & 63.0 & 21.1 & 0.62 & 39.6 & 6.99 & -131 \\
\hline $\mathrm{K} 1$ & 10.00 & 0.60 & 0.06 & -9.4 & 9.1 & 45.2 & 45.8 & 0.24 & 29.4 & 7.57 & -147 \\
\hline K2 & 4.99 & 0.32 & 0.06 & -4.67 & 5.1 & 28.6 & 66.3 & 0.29 & 27.9 & 7.52 & -134 \\
\hline K3 & 6.17 & 0.51 & 0.08 & -5.66 & 18.1 & 67.4 & 14.5 & 0.38 & 33.2 & 7.33 & -213 \\
\hline Mean & 10.43 & 1.77 & 0.17 & -8.66 & 13.2 & 58.5 & 28.3 & 0.98 & 57.4 & 7.53 & -155 \\
\hline
\end{tabular}



Fig. 2. Spatial distribution of the relative contents of SEM components in the surface sediments of the Xiaoqinghe estuary.

and the content of organic matter. Therefore, the ecological risks posed by anthropogenically originated heavy metals are much higher.

Pearson correlation matrix for the sediment components and geochemical parameters of the Xiaoqinghe estuary are shown in Table 3. All the metals and SEM components were significantly correlated with each other in the surface sediments of the Xiaoqinghe River, suggesting a major common origin of them in the sediments in this area. The wastewater discharged from human activities into the Xiaoqinghe River could be responsible for this (Wang et al., 2006). The concentrations of all the studied metals and the components of SEM were significantly correlated with the MC, which indicated that MC was an important impact factor for their spatial distribution, and this was consistent with the previous study in the offshore area of the Laizhou Bay (Gao et al., 2013). The concentrations of all the studied metals and the components of SEM were also significantly correlated with AVS, confirming that AVS was another important impacting factor on the spatial distribution of sedimentary heavy metals.

Negative correlations were observed for all the metals and [AVS] with Eh, indicating the redox status in the sediments of the studied area had a certain impact on the combination intensity between divalent metals and AVS; however, the correlations were not significant (Table 3). The concentrations of all the studied metals and AVS were not necessarily significantly correlated with TOC and $\mathrm{pH}$; only the concentration of $\mathrm{Cd}$ and $[\mathrm{SEM}]_{\mathrm{Pb}}$ were significantly correlated with silt and sand (Table 3 ). These facts suggested that the concentrations of heavy metals and AVS in sediments cannot be simply interpreted by the changes in grain size, $\mathrm{pH}$ and TOC concentrations (Fang et al., 2005; Ip et al., 2007; Liu et al., 2007).

The comparison between the concentrations of the measured metals and the ERL and ERM values indicated that bio-toxic risks could occur in the surface sediments of some sites in the Xiaoqinghe estuary (Table 1 ). These results may lead policy makers, managers and/or regulators to take actions to mitigate or remediate the negative impacts of heavy metals on these spots of the Xiaoqinghe estuary. Though the concentrations of heavy metals were high in the riverine sediments of the Xiaoqinghe estuary, the values of [SEM]/[AVS] revealed that the high AVS concentrations in the Xiaoqinghe River could reduce their bioavailability, thereby

Table 3

Pearson correlation matrix for the sediment components and geochemical parameters of the Xiaoqinghe estuary.

\begin{tabular}{|c|c|c|c|c|c|c|c|c|c|c|c|c|}
\hline & $\mathrm{Cd}$ & $\mathrm{Cu}$ & $\mathrm{Ni}$ & $\mathrm{Pb}$ & $\mathrm{Zn}$ & {$[\mathrm{SEM}]_{\mathrm{Cd}}$} & {$[\mathrm{SEM}]_{\mathrm{Cu}}$} & {$[\mathrm{SEM}]_{\mathrm{Ni}}$} & {$[\mathrm{SEM}]_{\mathrm{Pb}}$} & {$[\mathrm{SEM}]_{\mathrm{Zn}}$} & [SEM] & [AVS] \\
\hline $\mathrm{Cd}$ & 1 & $0.927^{b}$ & $0.867^{c}$ & $0.898^{\mathrm{b}}$ & $0.894^{b}$ & $0.958^{\mathrm{a}}$ & $0.949^{\mathrm{a}}$ & $0.817^{c}$ & $0.985^{\mathrm{a}}$ & $0.937^{b}$ & $0.942^{b}$ & $0.793^{c}$ \\
\hline $\mathrm{Cu}$ & & 1 & $0.972^{\mathrm{a}}$ & $0.939^{\mathrm{b}}$ & $0.977^{\mathrm{a}}$ & $0.991^{\mathrm{a}}$ & $0.997^{\mathrm{a}}$ & $0.886^{\mathrm{b}}$ & $0.936^{\mathrm{b}}$ & $0.993^{\mathrm{a}}$ & $0.994^{\mathrm{a}}$ & $0.925^{\mathrm{b}}$ \\
\hline $\mathrm{Ni}$ & & & 1 & $0.932^{\mathrm{b}}$ & $0.912^{\mathrm{b}}$ & $0.964^{\mathrm{a}}$ & $0.960^{\mathrm{a}}$ & $0.875^{\mathrm{b}}$ & $0.887^{\mathrm{b}}$ & $0.943^{\mathrm{a}}$ & $0.947^{\mathrm{a}}$ & $0.859^{c}$ \\
\hline $\mathrm{Pb}$ & & & & 1 & $0.918^{\mathrm{b}}$ & $0.942^{\mathrm{a}}$ & $0.944^{\mathrm{a}}$ & $0.928^{\mathrm{b}}$ & $0.941^{\mathrm{b}}$ & $0.947^{\mathrm{a}}$ & $0.949^{\mathrm{a}}$ & $0.798^{\mathrm{c}}$ \\
\hline $\mathrm{Zn}$ & & & & & 1 & $0.956^{\mathrm{a}}$ & $0.975^{\mathrm{a}}$ & $0.891^{\mathrm{b}}$ & $0.902^{\mathrm{b}}$ & $0.991^{\mathrm{a}}$ & $0.988^{\mathrm{a}}$ & $0.938^{b}$ \\
\hline$[\mathrm{SEM}]_{\mathrm{Cd}}$ & & & & & & 1 & $0.992^{\mathrm{a}}$ & $0.860^{c}$ & $0.958^{\mathrm{a}}$ & $0.985^{\mathrm{a}}$ & $0.987^{\mathrm{a}}$ & $0.882^{b}$ \\
\hline$[\mathrm{SEM}]_{\mathrm{Cu}}$ & & & & & & & 1 & $0.890^{\mathrm{b}}$ & $0.958^{\mathrm{a}}$ & $0.994^{\mathrm{a}}$ & $0.996^{\mathrm{a}}$ & $0.919^{b}$ \\
\hline$[\mathrm{SEM}]_{\mathrm{Ni}}$ & & & & & & & & 1 & $0.851^{\mathrm{c}}$ & $0.903^{\mathrm{b}}$ & $0.904^{\mathrm{b}}$ & $0.763^{c}$ \\
\hline$[\mathrm{SEM}]_{\mathrm{Pb}}$ & & & & & & & & & 1 & $0.944^{\mathrm{a}}$ & $0.949^{\mathrm{a}}$ & $0.817^{c}$ \\
\hline$[\mathrm{SEM}]_{\mathrm{Zn}}$ & & & & & & & & & & 1 & $1.000^{\mathrm{a}}$ & $0.915^{b}$ \\
\hline [SEM] & & & & & & & & & & & 1 & $0.914^{\mathrm{b}}$ \\
\hline [AVS] & & & & & & & & & & & & 1 \\
\hline Clay (\%) & 0.547 & 0.337 & 0.307 & 0.211 & 0.216 & 0.397 & 0.381 & 0.123 & 0.498 & 0.298 & 0.314 & 0.300 \\
\hline Silt (\%) & $0.848^{\mathrm{c}}$ & 0.707 & 0.628 & 0.579 & 0.647 & 0.738 & 0.746 & 0.546 & $0.808^{c}$ & 0.698 & 0.708 & 0.670 \\
\hline Sand (\%) & $-0.802^{\mathrm{c}}$ & -0.642 & -0.572 & -0.512 & -0.568 & -0.680 & -0.683 & -0.466 & $-0.759^{c}$ & -0.626 & -0.638 & -0.604 \\
\hline $\mathrm{pH}$ & 0.163 & 0.210 & 0.091 & 0.371 & 0.373 & 0.179 & 0.215 & 0.341 & 0.232 & 0.300 & 0.287 & 0.252 \\
\hline Eh & -0.594 & -0.306 & -0.213 & -0.479 & -0.310 & -0.374 & -0.373 & -0.413 & -0.610 & -0.369 & -0.377 & -0.144 \\
\hline TOC (\%) & 0.010 & 0.113 & 0.166 & 0.070 & 0.017 & 0.122 & 0.078 & 0.314 & 0.016 & 0.026 & 0.029 & 0.233 \\
\hline MC (\%) & $0.955^{\mathrm{a}}$ & $0.981^{\mathrm{a}}$ & $0.933^{\mathrm{b}}$ & $0.889^{b}$ & $0.958^{\mathrm{a}}$ & $0.981^{\mathrm{a}}$ & $0.985^{\mathrm{a}}$ & $0.862^{\mathrm{c}}$ & $0.936^{\mathrm{b}}$ & $0.979^{\mathrm{a}}$ & $0.980^{\mathrm{a}}$ & $0.897^{\mathrm{b}}$ \\
\hline
\end{tabular}

\footnotetext{
a $p<0.001$.

b $0.001<p<0.01$.

c $0.01<p<0.05$.
} 
reducing their potential bio-toxicity (Table 2). Generally, the concentrations of AVS in marine sediments were lower than those in riverine sediments, but the concentrations of heavy metals in marine sediments were also very low. Therefore, there were sufficient sulfide ions to combine the metal ions to eliminate their biotoxicity.

Both criteria used in this study have limitations in the assessment of the sediment quality. ERL and ERM guidelines are empirical approaches based on the total contents of metals in sediments (Long et al., 1995). It may be misleading to use only the total contents of metals in sediments to assess the toxicity or the bioavailability of metals, because different sediments have different degrees of metal bioavailability even with the same total content of metals. AVS concentration may change with the change of environmental conditions, and when this happens, the sediments without bio-toxic risks from heavy metals according to AVS-SEM criteria may suffer from their threats. When AVS is oxidized in the aerobic environment, the metals combining with AVS could be released into the water column. In addition, divalent sulfur ions released from AVS-rich sediments can combine with hydrogen ions to form $\mathrm{H}_{2} \mathrm{~S}$ which has a strong neurotoxicity and can produce toxic effects on aquatic life and even on humans; $\mathrm{H}_{2} \mathrm{~S}$ can also corrode ships, industrial equipment and pipelines (Jack et al., 1992; Kim and Kim, 2001). Therefore, AVS itself with extremely high concentration is a potential environmental threat.

Similar to the indication of some previous publications such as Wenning and Ingersoll (2002) and Hinkey and Zaidi (2007), based on the results of the present study, it is recommended that the assessment of heavy metal pollution in sediments should be validated with laboratory toxicity tests, benthic community analyses, bio-accumulation tests, or a combination of these when using SQGs to make decisions or take management actions to mitigate or remediate toxic effects from sedimentary metals in any water ecosystem.

Based on the ERL-ERM guidelines, $\mathrm{Cu}, \mathrm{Ni}$ and $\mathrm{Pb}$ might cause bio-toxic effect occasionally and $\mathrm{Zn}$ might cause bio-toxic effect frequently in the surface sediments of the Xiaoqinghe River. The surface sediments in the marine area were in good quality and only Ni might cause bio-toxic effect occasionally according to the ERL-ERM guidelines. Concentrations of Cd in all the sites were very low, and no ERL value of it was exceeded, so Cd can hardly cause any adverse effect in the studied area.

Despite the higher concentrations of the studied metals in riverine sediments, it seemed that bio-toxic effect could hardly occur, because these metals had combined with excessive sulfides in the sediments. Although the concentrations of AVS in marine sediments were lower than those in riverine sediments, they were in sufficient quantity to combine with the metals in the sediments. Therefore, the AVS-SEM method revealed that the bio-toxic levels of all the studied metals in the surface sediments of the Xiaoqinghe estuary were low.

It has been widely accepted that both the AVS-SEM and ERLERM criteria are valid methods in the evaluation of sediment quality. However, in this study, based on these two methods, inconsistent results were obtained in predicting the influence of heavy metals on the surrounding environment. So, in order to give more accurate predictions of the environmental impact of heavy metals before making any efficient management or regulatory decisions, it is necessary for researchers to compare the results based on different criteria for sediment quality assessment.

\section{Acknowledgements}

This study was co-supported by the National Natural Science Foundation of China (41376083), the Department of Science and Technology of Shandong Province (2012GHY11535) and the CAS/
SAFEA International Partnership Program for Creative Research Teams (Representative Environmental Processes and Resources Effects in Coastal Zones). The assistance of Qinghu Xu, Yong Zhang, Fengxia Zhou, Peimiao Li and Jinfeng Zhang in the sample collection and manuscript preparation is greatly appreciated.

\section{References}

Ankley, G.T., Di Toro, D.M., Hansen, D.J., 1996. Technical basis and proposal for deriving sediment quality criteria for metals. Environ. Toxicol. Chem. 15 (2), 2056-2066.

Chen, B., Huang, H.J., Yan, L.W., Mei, B., 2009. Sediment movement and the effect of wind to sediment transport near Xiaoqing River Estuary. Acta Oceanol. Sin. 32 (2), 104-112 (In Chinese with English abstract).

Cui, Y., Zhang, L.J., Luo, X.X., Zhang, X., 2013. Study on the water pollution and eutrophication in the Xiaoqing River Estuary. J. Ocean Univ. China 43 (2), 60-66 (In Chinese with English abstract).

De Jonge, M., Teuchies, J., Meire, P., Blust, R., Bervoets, L., 2012. The impact of increased oxygen conditions on metal-contaminated sediments part I: Effects on redox status, sediment geochemistry and metal bioavailability. Water Res. 46 (7), 2205-2214.

Di Toro, D.M., Mahony, J.D., Hansen, D.J., Scott, K.J., Hicks, M.B., Mayr, S.M., Redmond, M.S., 1990. Toxicity of cadmium in sediments: the role of acid volatile sulfide. Environ. Toxicol. Chem. 9 (12), 1487-1502.

Di Toro, D.M., McGrath, J.A., Hansen, D.J., Berry, W.J., Paquin, P.R., Mathew, R., Wu, K.U., Santore, R.C., 2005. Predicting sediment metal toxicity using a sediment biotic ligand model: methodology and initial application. Environ. Toxicol. Chem. 24 (10), 2410-2427.

Durán, I., Sánchez-Marín, P., Beiras, R., 2012. Dependence of $\mathrm{Cu}, \mathrm{Pb}$ and $\mathrm{Zn}$ remobilization on physicochemical properties of marine sediments. Mar Environ. Res. 77, 43-49.

Fang, T., Li, X., Zhang, G., 2005. Acid volatile sulfide and simultaneously extracted metals in the sediment cores of the Pearl River Estuary, South China. Ecotoxicol Environ. Saf. 61 (3), 420-431.

Gao, X.L., Chen, C.T.A., 2012. Heavy metal pollution status in surface sediments of the coastal Bohai Bay. Water Res. 46 (6), 1901-1911.

Gao, X.L., Li, P.M., Chen, C.T.A., 2013. Assessment of sediment quality in two important areas of mariculture in the Bohai Sea and the northern Yellow Sea based on acid-volatile sulfide and simultaneously extracted metal results. Mar. Pollut. Bull. 72 (1), 281-288.

Gao, X.L., Zhou, F.X., Chen, C.T.A., 2014. Pollution status of the Bohai Sea, China: An overview of the environmental quality assessment related trace metals. Environ. Int. 62, 12-30.

Guillen, G., Ruckman, M., Smith, S., Broach, L., 1993. Marina impacts in Clean Lake and Galveston Bay. Special Report D7-001A prepared for the Texas Wate Commission, Houston, TX.

Hinkey, L.M., Zaidi, B.R., Volson, B., Rodriguez, N., 2005. Identifying sources and distributions of sediment contaminants at two US Virgin Islands marinas. Mar Pollut. Bull. 50 (11), 1244-1250.

Hinkey, L.M., Zaidi, B.R., 2007. Differences in SEM-AVS and ERM-ERL predictions of sediment impacts from metals in two US Virgin Islands marinas. Mar. Pollut. Bull. 54 (2), 180-185.

Ip, C.C.M., Li, X.D., Zhang, G., Wai, O.W.H., Li, Y.S., 2007. Trace metal distribution in sediments of the Pearl River Estuary and the surrounding coastal area, South China. Environ. Pollut. 147 (2), 311-323.

Jack, R.F., Ringelberg D.B., White, D.C. 1992. Differential corrosion rates of carbon steel by combinations of Bacillus sp., Hafnia alvi and Desulfovibrivo gigas established by phospholipids analysis of electrode biofilm. Corros. Sci. 33 (12) 1843-1853.

Kim, J.G., Kim, Y.W., 2001. Cathodic protection criteria of thermally insulated pipeline buried in soil. Corros. Sci. 43 (11), 2011-2021.

Lambert, R., Grant, C., Sauvé, S., 2007. Cadmium and zinc in soil solution extracts following the application of phosphate fertilizers. Sci. Total Environ. 378 (1), 293-305.

Liu, J.C., Yan, C.L., Kate, L.S., Zhang, R.F., Lu, H.L., 2010. The distribution of acidvolatile sulfide and simultaneously extracted metals in sediments from a mangrove forest and adjacent mudflat in Zhangjiang Estuary, China. Mar. Pollut. Bull. 60 (8), 1209-1216.

Liu, J., Yan, C., Macnair, M.R., Hu, J., Li, Y., 2007. Vertical distribution of acid-volatile sulfide and simultaneously extracted metals in mangrove sediments from the Jiulong River Estuary, Fujian, China. Environ. Sci. Pollut. Res. 14 (5), 345-349.

Li, X.D., Wai, O.W.H., Li, Y.S., Coles, B.J., Ramsey, M.H., Thornton, I., 2000. Heavy metal distribution in sediment profiles of the Pearl River estuary, South China. Appl. Geochem. 15 (5), 567-581.

Long, E.R., Field, L.J., Mac Donald, D.D., 1998. Predicting toxicity in marine sediments with numerical sediment quality guidelines. Environ. Toxicol. Chem. 17 (4) 714-727.

Long, E.R., MacDonald, D.D., Smith, S.C., Calder, F.D., 1995. Incidence of adverse biological effects within ranges of chemical concentrations in marine and estuarine sediments. Environ. Manage. 19 (1), 81-97.

Ma, S.S., Xin, F.Y., Cui, Y., Qiao, X.Y., 2004. Assessment of main pollution matter volume into the sea from Yellow River and Xiaoqing River. Mar. Fish. Res. 25 (5), 47-51 (In Chinese with English abstract). 
McGrath, J.A., Paquin, P.R., Di Toro, D.M., 2002. Use of the SEM and AVS approach in predicting metal toxicity in sediments. Fact Sheet on Environmental Risk Assessment, vol. 10. International Council on Mining and Metals (ICMM), London, UK.

Prica, M., Dalmacija, B., Rončević, S., Krčmar, D., Bečelić, M., 2008. A comparison of sediment quality results with acid volatile sulfide (AVS) and simultaneously extracted metals (SEM) ratio in Vojvodina (Serbia) sediments. Sci. Total Environ. 389 (2-3), 235-244.

SOA (State Oceanic Administration of China), 2009. Marine Environment Quality Bulletin of China, 2008 <http://www.coi.gov.cn/gongbao/nrhuanjing/nr2008/ 201107/t20110729_18793.html>. (in Chinese).

SOA (State Oceanic Administration of China), 2012. Marine Environment Quality Bulletin of China, 2011. <http://www.coi.gov.cn/gongbao/nrhuanjing/nr2011/ 201207/t20120710_23199.html>. (in Chinese).

Soares, H.M.V.M., Boaventura, R.A.R., Machado, A.A.S.C., da Silva, J.C.G.E., 1999 Sediments as monitors of heavy metal contamination in the Ave river basin (Portugal): multivariate analysis of data. Environ. Pollut. 105 (3), 311-323.

USEPA (United States Environmental Protection Agency), 2004. The incidence and severity of sediment contamination in surface waters of the United States, National Sediment Quality Survey EPA-823-R-04-007, second ed. United States Environmental Protection Agency, Office of Science and Technology, Washington, DC.

van Den Berg, G.A., Loch, J.P.G., van Der Heijdt, L.M., Zwolsman, J.J.G., 1999. Mobilisation of heavy metals in contaminated sediments in the river Meuse, The Netherlands. Water Air Soil Pollut. 116 (3-4), 567-586. van Griethuysen, C., Gillissen, F., Koelmans, A.A., 2002. Measuring acid volatile sulfide in floodplain lake sediments: effect of reaction time, sample size and aeration. Chemosphere 47 (4), 395-400.

Wang, H.J., Yang, Z.S., Saito, Y., Liu, J.P., Sun, X.X., 2006. Interannual and seasonal variation of the Huanghe (Yellow River) water discharge over the past 50 years: Connections to impacts from ENSO events and dams. Global Planet. Change 50 (3-4), 212-225.

Wenning, R.J., Ingersoll, C.G., 2002. Summary of the SETAC Pellston workshop on use of sediment quality guidelines and related tools for the assessment of contaminated sediments Fairmont Montana USA. Society of Environmental Toxicology and Chemistry (SETAC), Pensacola, FL, USA, pp. 17-22.

Wilson, D.J., Chang, E., 2000. Bioturbation and the oxidation of sulfide in sediments. J. Tennessee Acad. Sci. 75, 76-85.

Yang, Y.Q., Chen, F.R., Zhang, L., Liu, J.S., Wu, S.J., Kang, M.L., 2012. Comprehensive assessment of heavy metal contamination in sediment of the Pearl River Estuary and adjacent shelf. Mar. Pollut. Bull. 64 (9), 1947-1955.

Zhang, H., Shan, B.Q., 2008. Historical records of heavy metal accumulation in sediments and the relationship with agricultural intensification in the YangtzeHuaihe region, China. Sci. Total Environ. 399 (1-3), 113-120.

Zhuang, W., Gao, X.L., 2013. Acid-volatile sulfide and simultaneously extracted metals in surface sediments of the southwestern coastal Laizhou Bay, Bohai Sea: Concentrations, spatial distributions and the indication of heavy metal pollution status. Mar. Pollut. Bull. 76 (1-2), 128-138. 